\title{
HUBUNGAN PERSEPSI TERHADAP LINGKUNGAN KERJA DENGAN PERILAKU INOVATIF KARYAWAN BAGIAN PENJUALAN
}

\author{
Lina Febriani Ayu Andon Dewi ${ }^{1}$, Reny Yuniasanti ${ }^{2}$, Sowanya Ardi Prahara ${ }^{3}$ \\ ${ }^{123}$ Universitas Mercu Buana Yogyakarta \\ ${ }^{1}$ lina.febriani117@gmail.com, ${ }^{2}$ reny.yuniasanti@gmail.com, ${ }^{3}$ sowanya_hara@yahoo.com
}

\begin{abstract}
Abstrak
Agar dapat bertahan di era disruptive setiap perusahaan menuntut karyawannya untuk bisa lebih inovatif dalam proses kerjanya. Masih rendahnya perilaku inovatif di PT. A terutama pada bagian penjualan menjadi permasalahan yang harus dicarikan bentuk intervensi yang tepat. Hipotesis penelitian yaitu terdapat hubungan antara persepsi karyawan terhadap lingkungan kerja dengan perilaku inovatif dalam pekerjaan. Subjek dalam penelitian ini terdiri dari 35 karyawan penjualan PT. A Yogyakarta yang dipilih dengan menggunakan purposive sampling. Subjek penelitian adalah karyawan tetap dengan masa kerja minimal setahun. Pengumpulan data menggunakan alat ukur skala persepsi lingkungan kerja dan skala perilaku inovatif. Dari hasil analisis data menggunakan korelasi product moment Pearson, diketahui terdapat hubungan positif dan signifikan antara persepsi lingkungan kerja dengan perilaku inovatif penjualan karyawan PT. A Yogyakarta $(r=0,439 ; \mathrm{p}$ $<0,050$ ). Persepsi lingkungan kerja secara efektif berkontribusi sebesar $13,90 \%$ terhadap perilaku inovatif karyawan. Berdasarkan analisis regresi, diketahui bahwa persepsi lingkungan kerja fisik memberikan kontribusi efektif sebesar $11,70 \%$, dan persepsi lingkungan kerja non fisik secara efektif berkontribusi sebesar $17,40 \%$ pada perilaku inovatif. Berdasarkan hasil penelitian ini memberikan informasi intervensi untuk lebih menyelaraskan dan mengharmoniskan hubungan di dalam organisasi untuk memunculkan perilaku inovatif karyawan.
\end{abstract}

Kata Kunci: perilaku inovatif, persepsi lingkungan kerja, karyawan penjualan

\section{THE CORRELATION BETWEEN PERCEPTION OF WORK CLIMATE AND INOVATIVE BEHAVIOUR MARKETING EMPLOYEE}

\author{
Lina Febriani Ayu Andon Dewi ${ }^{1}$, Reny Yuniasanti ${ }^{2}$, Sowanya Ardi Prahara ${ }^{3}$ \\ ${ }^{123}$ Universitas Mercu Buana Yogyakarta \\ ${ }^{1}$ lina.febriani117@gmail.com, ${ }^{2}$ reny.yuniasanti@gmail.com, ${ }^{3}$ sowanya_hara@yahoo.com
}

\begin{abstract}
In order to survive in the disruptive era every company demands their employees to be more innovative in the process of working. PT. A still have low innovative behaviour, particularly in the sales department that condition becomes a problem that must be sought to exact interventions. The hypothesis of the research is there is a relationship between employee perceptions to work environment with innovative behaviour in work. Hypotheses of this study is to know there any relation between sales employees' perception of work environment with the innovative behavior in their daily work. Subject in this study consists of 35 sales employees of PT. A Yogyakarta which are chosen by using purposive sampling. They are chosen based on the statues of permanent employees and have length of work minimum a year. Data were collected by using measuring instrument of scale perception on work environment and innovative behavior scale. Based on data analyzed result with correlation of product moment Pearson, it can be concluded that there is positive and significant relationship between perceptions of the work environment with innovative behavior sales employees of PT. A Yogyakarta $(r=0.439$ ( $\mathrm{p}<0.050)$. The perceptions of the work environment effectively
\end{abstract}


contribute amount $13.90 \%$ to the employees' innovative behavior. Based regression analyzes of each aspect, it is known that perception of physical work environment provides effective contribution amount to $11,70 \%$, and perception of non-physical work environment effectively contribute amount to $17,40 \%$ of innovative behavior. Based on the results of this study provide information on the intervention to better align and harmonize relationships within the organization to elicit innovative behavior of employees.

Keywords: perception of work environment, innovative behavior, sales employee.

\section{PENDAHULUAN}

Di era disruptive ini membutuhkan sumber daya manusia yang berkualitas dan inovatif, hal ini diperlukan agar perusahaan mampu memenangkan persaingan dalam dunia bisnis (Kasali, 2017). Salah satunya dengan memanfaatkan kemampuan yang di miliki oleh karyawan untuk turut serta dalam proses inovasi (Ancok, 2012).

PT. A Yogyakarta memiliki visi menjadi salah satu perusahaan dengan pengelolaan terbaik di Asia Pasifik dengan penekanan pada pertumbuhan yang berkelanjutan dengan pembangunan kompetensi melalui pengembangan sumber daya manusia, struktur keuangan yang solid, kepuasan pelanggan dan efisiensi serta menjadi perusahaan yang mempunyai tanggung jawab sosial serta ramah lingkungan. Adanya visi tersebut diharapkan agar seluruh karyawan PT. A dapat memaksimalkan pekerjaanya. Salah satu caranya dengan terus meningkatkan perilaku inovatif pada seluruh karyawan.

Perilaku inovatif merupakan keseluruhan tindakan individu yang mengarah pada pemunculan, pengenalan, dan penerapan dari sesuatu yang baru dan menguntungkan pada seluruh tingkat organisasi (Kleysen \& Street, 2001). Selanjutnya Kanter (dalam Janssen, 2003) menyebutkan perilaku inovatif memiliki tiga aspek yaitu: Idea generation pada tahap ini individu mampu menghasilkan sesuatu yang baru berupa ide-ide yang bermanfaat. Idea promotion pada tahap individu yang sudah mampu menghasilkan ide baru, berusaha mengajak individu lain untuk mendukung ide yang dimilikinya. Idea generalization pada tahap ini individu mewujudkan ide dengan menghasilkan model inovasi yang dapat dijadikan pengalaman dan diaplikasikan dalam suatu peran kerja di dalam organisasi.

Penelitian terbaru mengenai perilaku inovatif yang dilakukan oleh Sari dan Ulfa (2013) menunjukkan bahwa perilaku inovasi karyawan dalam perusahaan masih tergolong rendah. Begitu pula di PT. A yang menunjukkan masih rendahnya perilaku inovatif karyawan di bagian penjualan berdasarkan hasil wawancara pada manager penjualan dan lima karyawan 
bagian penjualan PT. A Yogyakarta pada hari jumat tanggal 11 Maret 2016. Hasil wawancara menunjukkan sepanjang kuartal satu tahun 2015 penjualan produk perusahaan mengalami kemrosotan, dan karyawan dinilai belum memiliki ide-ide inovatif untuk menyelesaikan permasalahan penjualan. Selain itu karyawan menyatakan masih merapkan cara penjualan yang telah ada dan belum memperoleh ide-ide baru yang berhasil untuk meningkatkan penjualan . Kondisi tersebut menyebabkan banyak karyawan yang tidak melakukan usaha mencari ataupun mengajak teman-teman yang lain untuk berusaha mewujudkan ide-ide baru dalam penjualan. Proses yang terjadi mengakibatkan belum adanya suatu model inovasi baru penjualan yang dapat dilaksanakan dalam sistem kerja organisasi. Belum munculnya idea generation, idea promotion dan idea generalization pada karyawan penjualan tersebut tentunya menjadi tantangan besar bagi PT A Yogyakarta lebih meningkatkan perilaku inovatif karyawan khususnya bagian penjualan untuk dapat meningkatkan penjualan yang saat ini belum mencapai target.

Menurut Ancok (2012) perilaku inovatif dapat dipengaruhi oleh beberapa faktor yaitu modal manusia, modal kepemimpinan, dan modal struktural organisasi. Ambile menambahkan (dalam
Ancok, 2012) faktor lain yang juga turut serta mempengaruhi perilaku inovatif karyawan adalah kondisi lingkungan kerja yang kondusif dan kreatif. Pendapat tersebut menunjukkaab bahwa lingkungan kerja diprediksi dapat mempengaruhi munculnya perilaku inovatif pada karyawan.

Sedarmayanti (2009) mengartikan lingkungan kerja adalah keseluruhan alat perkakas dan bahan yang dihadapi. Adapun hal-hal tersebut adalah lingkungan sekitar di mana seseorang bekerja, metode kerjanya, serta pengaturan kerjanya baik perseorangan maupun sebagai kelompok. Netisemito (2001) lingkungan kerja adalah segala sesuatu yang ada di sekitar para pekerja yang dapat mempengaruhi dirinya dalam menjalankan tugas-tugas yang diembankan.

$$
\text { Sedarmayanti }
$$

mendefinisikan persepsi terhadap lingkungan kerja sebagai cara pandang karyawan terhadap lingkungan sekitar di mana dia bekerja yang berkaitan dengan alat kerjanya, bahan, metode kerjanya, serta pengaturan kerjanya baik perseorangan maupun sebagai kelompok. Sedarmayanti (2009) juga membagi aspek persepsi terhadap lingkungan kerja menjadi dua yaitu: aspek fisik dan nonfisik. 
Karyawan akan memiliki persepsi baik terhadap lingkungan kerja apabila berada di lingkungan kerja yang kondusif, yang akan memberikan rasa aman serta nyaman (Sarwono, 2005). Persepsi merupakan cara pandang seseorang terhadap suatu hal yang didapatnya dari stimulus yang di lihat maupun yang didengarnya. Hal tersebut sesuai dengan pendapat Robbins (2003) yang menyatakan bahwa persepsi merupakan kesan yang diperoleh individu melalui panca indra kemudian di analisis (diorganisir), diinterpretasi dan kemudian dievaluasi. Sehingga individu tersebut memperoleh makna. Melalui proses persepsi ini individu akan membuat kesimpulan tentang sesuatu yang diterimanya.

Lingkungan kerja yang kondusif adalah keadaan yang di harapkan oleh setiap karyawan. Hal ini karena lingkungan yang kondusif akan membuat karyawan merasa aman serta nyaman berada di dalamnya dan dapat memunculkan semangat karyawan untuk membuat ide-ide baru, sehingga akan mempengaruhi sikap individu dalam memunculkan perilaku inovatifnya.

\section{Perilaku Inovatif dan Persepsi Terhadap Lingkungan Kerja}

Persepsi lingkungan kerja memiliki dua aspek yaitu aspek lingkungan fisik dan non-fisik (Sedarmayanti, 2009). Aspek lingkungan fisik ini kemudian dibagi menjadi dua kategori yaitu lingkungan yang langsung berhubungan dengan karyawan dan lingkungan perantara atau lingkungan umum. Sedangkan lingkungan kerja non-fisik adalah hubungan yang dibangun antara atasan dan sesama rekan kerja.

Lingkungan yang langsung berhubungan dengan karyawan itu seperti: pusat kerja, meja, kursi dan lain sebaginya merupakan bagian yang akan digunakan saat bekerja (Sedarmayanti, 2009). Benda-benda tersebut dapat dipersepsi nyaman atau tidak oleh karyawan, hal tersebut dapat memberikan dampak positif maupun negatif pada karyawan, dampak positifnya akan membantu menyelesaikan pekerjaan karyawan sehingga karyawan fokus memikirkan ide-ide inovatif yang akan di gunakan pada saat aplikasi di lapangan. Sebaliknya dampak negatif yang akan dirasakan oleh perusahaan apabila karyawan merasa tidak nyaman berada di tepat kerja adalah minimnya ide inovatif yang di munculkan karyawan dapat menghambat pengaplikasian ketika di lapangan (Ambile, 1999).

Lingkungan kerja non-fisik tidak kalah pentingnya dengan lingkungan kerja fisik, lingkungan non-fisik ini akan memberikan dampak psikologis pada 
karyawan. Dampak positif yang akan muncul apabila karyawan merasa nyaman berada di tempat kerja adalah karyawan mudah konsentrasi memikirkan ide-ide inovatif yang akan di gunakan di lapangan. Adapun dampak negatif apabila karyawan merasa kurang nyaman berada di tempat kerja, maka karyawan akan sulit berkonsentrasi menemukan ide-ide yang bersifat inovatif yang dapat melancarkan pekerjaanya (Ambile, 1999).

Aspek dari lingkungan kerja nonfisik yaitu hubungan dengan atasan dan hubungan dengan sesama rekan kerja (Sedarmayanti, 2009). Hubungan dengan atasan dapat bersifat positif maupun negatif.

Hubungan dengan atasan yang positif adalah hubungan yang terjalin baik antara atasan dengan bawahan, sehingga memudahkan karyawan dalam mendiskusikan segala hal yang berhubungan dengan pekerjaan. Bila karyawan mempersepsikan hubungan antara atasan dan bahwan serta rekan kerjanya yang menyenangkan dan terasa nyaman akan memunculkan keberanian dari karyawan. Keberanian dan kenyamanan ini akan memudahkan karyawan dalam mentransfer ide-ide inovatifnya kepada atasan agar segera mendapatkan persetujuan dan juga dapat di jadikan program yang dapat di jalankan. Sebaliknya bila karyawan mempersepsikan hubungan negatif antara atasan dengan bawahan adalah maka akan mengahambat karyawan mendiskusikan gagasan ataupun ide-ide yang dimilikinya.

Hubungan dengan sesama rekan kerja juga dapat bersifat positif maupun negatif. Hubungan positif antar sesama rekan kerja adalah hunbungan yang terjalin baik antar teman sekerja, hubungan baik di sini maksudnya adalah hubungan antar teman yang saling membantu dan berbagi dalam melakukan pekerjaan. Rekan kerja dapat memberikan dukungan ataupun memberikan sumbangan ide-ide inovatif kepada teman-teman tim untuk didiskusikan agar dapat di jadikan program yang dapat di jalankan. Sebaliknya hubungan negatif akan terjalin apabila antar sesama rekan kerja tidak saling memberikan dukungan untuk memperjuangkan ide-ide ataupun gagasan yang dimilikinya oleh karyawan. Hal ini akan menghambat karyawan untuk mengemukakan ide-ide yang ditemukanya.

Oleh sebab itu, karyawan yang merasa mendapatkan kemudahaan dalam mengekspresikan kemampuan yang dimilikinya baik itu dengan atasan maupun dengan sesama rekan kerja maka akan sangat mudah bagi karyawan menuangkan ide ataupun gagasan yang dimilikinya untuk kemudian diperjuangkan dan menjadi aplikasi atau 
program yang akan di jalankan. Sebaliknya apabila karyawan merasa sangat sulit dalam mengekspresikan kemampuan yang dimilikinya baik itu kepada atasan maupun teman kerja maka hal tersebut akan memberikan dampak negatif pada perusahaan, karena hal tersebut menghambat karyawan untuk menungkan ide-ide yang dimilikinya.

Hasil penelitian yang dilakukan Sari dan Ulfa (2013) dalam jurnalnya yang berjudul Perilaku Inovasi Karyawan Ditinjau dari Empat Kuadran Iklim Organisasi menunjukkan bahwa iklim organisasi memiliki tiga kuadran yang berhubungan dengan perilaku inovasi yaitu kuadran human relation model, kuadran rational goal model, dan kuadran open system model. Kuadran human relation model menekankan pada kesejahteraan, pertumbuhan dan komiten komunitas pekerja dalam organisasi. Kuadran rational goal model menekankan pada produktivitas dan pencapaian tujuan.

Dan kuadran open system model menekankan pada interaksi dan adaptasi terhadap organisasi di lingkunganya. Manager mencari sumber-sumber dan inovasi dalam merespon lingkungan atau pasarnya. Norma dan nilai diasosiasikan dengan pertumbuhan, akuisisi sumber daya, kreativitas dan adaptasi.

Berdasarkan penjelasan diatas sudah jelas bahwa lingkungan kerja berpengaruh terhadap banyak hal, seluruh kegiatan yang ada di perusahaan dipengaruhi dengan bagaimana situasi dan kondisi di tempat kerja. Persepsi karyawan terhadap lingkungan kerja merupakan salah satu penyebab dari keberhasilan dalam melaksanakan suatu pekerjaan, tetapi juga dapat menyebabkan suatu kegagalan dalam pelaksanaan suatu pekerjaan, karena lingkungan kerja dapat mempengaruhi pekerja terutama lingkungan kerja yang bersifat psikologis, dan pengaruhnya sendiri dapat bersifat positif maupun negatif.

Hal ini memberikan bukti bahwa persepsi terhadap lingkungan kerja berhubungan erat dengan perilaku inovatif para karyawan untuk memaksimalkan kinerjanya. Berdasarkan uraian di atas hipotesis penelitiannya adalah ada hubungan positif antara persepsi terhadap lingkungan kerja dengan perilaku inovatif karyawan. Semakin positif persepsi terhadap lingkungan kerja maka akan semakin tinggi perilaku inovatif karyawannya. Begitupun sebaliknya semakin negatif persepsi terhadap lingkungan kerja maka akan semakin rendah perilaku inovatif karyawanya.

\section{METODE}

Variabel-variabel yang digunakan dalam peelitian ini adalah sebagai berikut:

a. Perilaku Inovatif 
Perilaku inovatif adalah kemampuan individu untuk menampilkan, mempromosikan dan mengimplementasikan ide baru di dalam suatu pekerjaan, yang berhubungan dengan proses, produk dan prosedur yang mengarah pada tujuan organisasi.

Perilaku inovatif meliputi idea generation, idea promotion, dan idea realization Kanter (dalam Janssen, 2003). Perilaku inovatif diukur dengan menggunakan skala perilaku inovatif yang disusun oleh peneliti. Skor total yang diperoleh subjek merupakan cara untuk menentukan tinggi rendahnya perilaku inovatif karyawan yang dimilikinya. Semakin tinggi skor total yang diperoleh subjek, semakin tinggi pula perilaku inovatif karyawan.

\section{b. Persepsi Terhadap Lingkungan Kerja}

Persepsi terhadap lingkungan kerja sebagai proses melihat, mendengar dan merasakan karyawan terhadap lingkungan sekitar di mana dia bekerja yang berkaitan dengan alat kerjanya, bahan, metode kerjanya, serta pengaturan kerjanya baik perseorangan maupun sebagai kelompok.

Persepsi terhadap lingkungan kerja meliputi kondisi fisik dan non-fisik (Sedarmayanti, 2009). Persepsi terhadap lingkungan kerja diukur dengan menggunakan skala persepsi terhadap lingkungan kerja yang disusun oleh peneliti. Skor total yang diperoleh subjek merupakan cara untuk menentukan tinggi rendahnya persepsi terhadap lingkungan kerja karyawanyang dimilikinya. Semakin tinggi skor total yang diperoleh subjek, maka akan semakin positif persepsi terhadap lingkungan kerja.

\section{Subjek Penelitian}

Subjek dalam penelitian ini adalah karyawan PT. A Yogyakarta bagian penjualan. Menggunakan purposive sampling subjek penelitian di ambil dari populasi sebesar 35 orang karyawan. Adapun kriteria subjek dalam penelitian ini adalah karyawan tetap PT. A Yogyakarta bagian penjualan yang aktif bekerja dengan masa kerja minimal satu tahun. Karyawan tetap dengan masa kerja minimal satu tahun atau lebih diasumsikan telah memiliki banyak pengalaman kerja dan melakukan interaksi dengan lingkungan di perusahaan tersebut (Sedarmayanti, 2009).

\section{Metode Pengumpulan Data}

Alat pengumpulan data yang digunakan adalah menggunakan skala. Kedua skala yang dipakai dalam penelitian ini menggunakan 4 alternatif jawabanya itu: Skala 1 Hampir selalu (HS), sangat sering (SS), sangat jarang (SJ), Hampir Tidak Pernah (HTP). Skala 2 sangat sesuai (SS), sesuai (S), tidak sesuai (TS), dan sangat tidak sesuai (STS). 
Skala yang digunakan dalam penelitian ini adalah:

a. Skala Perilaku Inovatif

Skala Perilaku Inovatif terdiri dari 20 aitem dengan 9 butir pernyataan favorable dan 11 butir pernyataan unfavorable. Dalam penelitian ini, Skala Perilaku Inovatif disusun berdasarkan 3 aspek menurut Kanter (dalam Janssen, 2003) yaitu: idea generation, idea promotion, dan idea realization.

Skor koefisien validitas aitem berkisar antara $0,207-0,567$ dan koefisien reliabilitas alpha sebesar 0,820

b. Skala Persepsi Terhadap Lingkungan Kerja
Skala persepsi terhadap lingkungan kerja terdiri dari 7 butir pernyataan favorable dan 9 butir pernyataan unfavorable. Pada penelitian ini, skala persepsi terhadap lingkungan kerja disusun berdasarkan 2 aspek menurut Sedarmayanti (2009) yaitu: kondisi fisik dan non fisik. Skor koefisien validitas aitem berkisar antara $0,228-0,555$ dan koefisien reliabilitas alpha sebesar 0,760 .

\section{HASIL DAN PEMBAHASAN}

Berdasarkan data penelitian yang diperoleh, maka dapat diketahui distribusi subjek penelitian berdasarkan masa kerja dapat dilihat pada tabel 1 .

Tabel 1. Deskripsi Subjek Penelitian

\begin{tabular}{cccc}
\hline Aspek & Kategori & Total & Persentase \\
\hline & 1 tahun & 4 & $11,429 \%$ \\
& 2 tahun & 10 & $28,571 \%$ \\
Masa kerja & 3 tahun & 12 & $34,286 \%$ \\
& 4 tahun & 3 & $8,571 \%$ \\
& 5 tahun & 2 & $5,714 \%$ \\
& 6 tahun & 1 & $2,857 \%$ \\
& 7 tahun & 2 & $5,714 \%$ \\
\hline
\end{tabular}

Dilihat dari masa kerja, subjek penelitian paling banyak yaitu pada rentang masa kerja 3 tahun. Berdasarkan data yang terkumpul dari proses penelitian di peroleh skor empirik dan perhitungan skor hipotetik dari variabel perilaku inovatif dan persepsi terhadap lingkungan kerja.

Berdasarkan hasil perhitungan data empirik variabel perilaku inovatif memiliki skor minimal 20, skor maksimal
43 dan standar deviasinya ( $\sigma)$ 4,937. Mean hipotetik dari variabel perilaku inovatif dihitung dengan $(20+80): 2=50$, dan standar deviasinya $(\sigma)$ dihitung dengan (80-20):6 = 10. Variabel persesi terhadap lingkungan kerja memperoleh hasil perhitungan data empirik dengan skor minimal 16, skor maksimal 36 dan standar deviasinya $(\sigma) 27,11$. Mean $(\mu)$ hipotetik dari variabel persepsi terhadap lingkungan kerja dihitung dengan 
$(16+64): 2=40$ dan standar deviasinya $(\sigma)$ dihitung dengan (64-16):6 = 8 .

Berdasarkan data deskriptif, maka dapat dilakukan pengkategorisasian pada kedua variabel penelitian. Kategorisasi yang akan digunakan adalah kategorisasi jenjang berdasarkan distribusi normal.

Tabel 2. Kategorisasi Perilaku Inovatif

\begin{tabular}{ccc}
\hline Frekuensi & Presentase & Kategorisasi \\
\hline 30 & $85,714 \%$ & Rendah \\
5 & $14,286 \%$ & Sedang \\
0 & $0 \%$ & Tinggi \\
\hline
\end{tabular}

Tabel 3. Kategorisasi Persepsi terhadap Lingkungan Kerja

\begin{tabular}{ccc}
\hline Frekuensi & Presentase & Kategorisasi \\
\hline 31 & $88,571 \%$ & Negatif \\
4 & $11,429 \%$ & Netral \\
0 & $0 \%$ & Positif \\
\hline
\end{tabular}

\section{Uji Prasyarat}

Hasil uji normalitas sebaran data perilaku inovatif dari KolmogorovSmirnov diperoleh nilai $\mathrm{KS}-\mathrm{Z}=0,116$ dengan $p=0,200(p>0,050)$ sehingga dapat disimpulkan bahwa variabel perilaku inovatif mengikuti sebaran data yang normal, dan variabel persepsi terhadap lingkungan kerja menunjukan nilai $K S-Z=0,163$ dengan $p=0,019(p>$ 0,050) maka disimpulkan bahwa variabel persepsi terhadap lingkungan kerja tidak mengikuti sebaran data yang normal.

Hasil uji linieritas di peroleh nilai $\mathrm{F}$ linier sebesar 8,305 dengan $\mathrm{p}$ sig sebesar $0,009(\mathrm{p}<0,050)$. Dengan demikian, dapat disimpulkan bahwa terdapat hubungan linier antara variabel perilaku inovatif dengan variabel persepsi terhadap lingkungan kerja.

\section{Uji Hipotesis}

Hasil analisis korelasi product moment diperoleh koefisien korelasi korelasi sebesar $\mathrm{r}=0,439 \quad(\mathrm{p}<0,050)$. Koefisiensi determinasi $\left(K^{2}\right)$ sebesar 0,139. Hasil tersebut menunjukkan persepsi terhadap lingkungan kerja memberikan sumbangan efektif sebesar $13,90 \%$ terhadap perilaku inovatif pada karyawan bagian penjualan PT. A Yogyakarta, sedangkan sebesar 86,10\% di pengaruhi oleh faktor lain.

\section{Uji Tambahan}

Uji tambahan dengan menggunakan regresi menunjukkan hubungan antara persepsi terhadap lingkungan kerja fisik dengan perilaku inovatif dengan nilai korelasi sebesar $r=0,342 \quad(p<0,050)$, dengan nilai koefisien determinasi $\left(K^{2}\right)$ sebesar 0,117. Hal ini berarti bahwa persepsi terhadap lingkungan fisik memberikan sumbangan efektif sebesar $11,70 \%$ terhadap perilaku inovatif pada karyawan bagian penjualan PT. X Yogyakarta sedangkan 88,30\% dipengaruhi faktor-faktor lain.

Sedangkan hubungan antara persepsi terhadap lingkungan kerja nonfisik dengan perilaku inovatif diperoleh nilai korelasi sebesar $r=0,417$ dan 
$(\mathrm{p}<0,050)$, dengan nilai koefisiensi determinasi sebesar 0,174 . Hal ini berarti bahwa persepsi terhadap lingkungan kerja non-fisik memberikan sumbangan efektif sebesar $17,40 \%$ terhadap perilaku inovatif pada karyawan bagian penjualan PT. A Yogyakarta, sedangkan $82,60 \%$ dipengaruhi oleh faktor-faktor lain.

Tabel 4. Koefisiensi Regresi Setiap Aspek Persepsi Terhadap Lingkungan Kerja

\begin{tabular}{ccccc}
\hline Aspek & Nilai R & P Sig & $\boldsymbol{R}^{\mathbf{2}}$ & Presentase (\%) \\
\hline Lingkungan Fisik & 0,341 & 0,045 & 0,116 & $11,60 \%$ \\
Lingkungan Non-fisik & 0,428 & 0,010 & 0,183 & $18,30 \%$ \\
\hline
\end{tabular}

\section{Pembahasan}

Hasil analisis di atas menunjukan bahwa adanya hubungan positif antara persepsi terhadap lingkungan kerja dengan perilaku inovatif pada karyawan bagian penjualan PT. A Yogyakarta diterima secara signifikan, semakin positif persepsi karyawan terhadap lingkungan kerja maka akan cenderung semakin tinggi perilaku inovatifnya $(r=0,439$ $(p<0,050))$. Sebaliknya, semakin negatif persepsi karyawan terhadap lingkungan kerja, maka akan cenderung semakin semakin rendah perilaku inovatif karyawan. Hasil penelitian ini sesuai dengan hasil penelitian yang dilakukan oleh Sari \& Ulfa (2013) yang menyatakan bahwa iklim organisasi memiliki hubungan yang positif dengan perilaku inovatif.

Persepsi terhadap lingkungan kerja merupakan variabel yang merefleksikan perasaan evaluatif antara harapan dengan kenyataan mengenai kondisi lingkungan kerjanya, baik secara keseluruhan maupun dari berbagai aspek pekerjaanya (Spector,
1997). Lebih lanjut persepsi terhadap lingkungan kerja merupakan salah satu faktor yang mempengaruhi perilaku inovatif pada karyawan dalam suatu perusahaan, sehingga perusahaan sangat berkepentingan untuk berusaha meningkatkan perilaku inovatif menjadi setinggi mungkin.

Berdasarkan hasil kategorisasi skala perilaku inovatif, diketahui bahwa subjek penelitian memiliki perilaku inovatif dalam tingkat rendah 30 orang $(85,714 \%)$ dan sisanya 5 orang $(14,286 \%)$ dalam tingkat sedang. Subjek penelitian yang memiliki perilaku inovatif dalam kategori rendah artinya subjek belum dapat menemukan ide dan melihat kenyataan di lapangan tentang apa yang di bubutuhkan masyarakat, selain dari pada itu karyawan juga masih belum memiliki keberanian untuk menyampaikan dan juga memperjuangkan apa yang ada di dalam dirinya baik kepada atasan maupun kepada sesama rekan kerja. Karyawan masih belum dapat mengaplikasikan kemampuan yang di milikinya baik itu 
dalam sebuah bentuk program ataupun prosedur yang dapat di jalankan untuk menyelesaikan permasalahan yang sedang di hadapinya.

Hal tersebut sesuai dengan asumsi dan hasil wawancara serta observasi yang peneliti lakukan di lapangan bahwa perilaku inovatif yang dimiliki karyawan bagian penjualan masih rendah. Bahkan untuk kategorisasi tinggi tidak ada sama sekali. Jadi bisa dikatakan bahwa hampir seluruh subjek penelitian memiliki perilaku inovatif yang rendah.

Selanjutnya hasil pengkategorisasian persepsi terhadap lingkungan kerja menunjukkan bahwa sebagian besar subjek penelitian memiliki persepsi terhadap lingkungan kerja yang negatif sebanyak 31 orang $(88,571 \%)$ dan sisanya 4 orang $(11,429 \%)$ dalam kategori netral, artinya sebagian besar subjek penelitian memiliki persepsi negatif terhadap lingkungan kerja. Hal ini membuktikan bahwa di PT.A lingkungan kerja dipersepsikan kurang mendukung serta peran pemimpin dan rekan kerja yang masih menghambat karyawan untuk memperoleh kesempatan untuk berkembang dalam perusahaan.

$$
\text { Persepsi positif terhadap }
$$
lingkungan kerja merupakan hal yang diharapkan oleh setiap karyawan. Sedarmayanti (2009) menjelaskan kondisi lingkungan kerja yang kondusif adalah lingkungan kerja yang memberikan rasa aman serta nyaman. Selain itu rekan kerja yang saling terbuka dan saling mendukung dan hubungan yang baik dengan atasan ataupun bawahan juga turut berperan penting mewujudkan persepsi positif terhadap lingkungan kerja.

Uji tambahan yang dilakukan untuk menentukan seberapa besar pengaruh dari tiap-tiap aspek persepsi lingkungan kerja terhadap perilaku inovatif mendapatkan hasil bahwa persepsi terhadap lingkungan kerja non-fisik memberikan sumbangan sebesar $17,40 \%$ terhadap perilaku inovatif pada karyawan. Sedangkan persepsi terhadap lingkungan kerja fisik hanya memberikan sumbangan sebesar $11,70 \%$ terhadap perilaku inovatif pada karyawan.

Berdasarkan hasil uji tambahan persepsi terhadap lingkungan kerja nonfisik memberikan sumbangan lebih besar dari pada persepsi terhadap lingkungan fisik. Hal ini disebabkan karyawan yang bekerja di PT. A Yogyakarta sudah banyak yang melebihi 1 tahun masa kerja sehingga hal ini memungkinkan karyawan sudah membangun hubungan dengan sesama rekan kerja dan juga atasan yang stabil.

Hasil penelitian menunjukkan koefisien determinasi $\left(K^{2}\right)$ sebesar 0,139. Berarti persepsi terhadap lingkungan kerja merupakan variabel yang memberikan sumbangan terhadap meningkatnya 
perilaku inovatif karyawan bagian penjualan sebesar $13,90 \%$. Data penelitian ini juga sesuai denga hasip penelitian dari Wuri \& Suhariadi (2015) dalam jurnalnya yang berjudul Hubungan Iklim Organisasi dengan Perilaku Kerja Inovatif Pada Karyawan Industri Kreatif menunjukan bahwa terdapat hubungan positif antara iklim organisasi dengan perilaku kerja inovatif pada karyawan industri kreatif. Hal ini membuktikan bahwa persepsi terhadap lingkungan kerja berpengaruh signifikan terhadap perilaku inovatif karyawan. Semakin tinggi persepsi terhadap lingkungan kerja dalam individu, maka semakin tinggi kinerja yang dimiliki individu tersebut.

\section{KESIMPULAN}

Berdasarkan hasil analisis penelitian, maka diperoleh kesimpulan bahwa hipotesis penelitian ini diterima, yaitu ada hubungan yang signifikan antara perilaku inovatif dengan persepsi terhadap lingkungan kerja pada karyawan bagian penjualan PT. A Yogyakarta. Artinya semakin positif nilai persepsi terhadap lingkungan kerja maka akan semakin tinggi perilaku inovatif yang dimiliki karyawan tersebut. Sebaliknya semakin negatif nilai persepsi terhadap lingkungan kerja maka akan semakin rendah perilaku inovatifnya.
Persepsi terhadap lingkungan kerja memberikan sumbangan sebesar 13,90\% terhadap perilaku inovatif pada karyawan bagian penjualan PT. A Yogyakarta. berdasarkan hasil uji tambahan peraspek persepsi terhadap lingkungan kerja fisik memberikan sumbangan efektif sebesar $11,70 \%$ terhadap perilaku inovatif karyawan. Sedangkan persepsi terhadap lingkungan non-fisik memberikan sumbangan efektif sebesar 17,40\% terhadap perilaku inovatif karyawan. Hal ini berarti bahwa persepsi terhadap lingkungan kerja non-fisik memberikan pengaruh lebih besar terhadap perilaku inovatif, dari pada persepsi terhadap lingkungan fisiknya.

\section{DAFTAR PUSTAKA}

Ambile, T, M., \& Counti, R. (1999). Changes in the work Environment for Creativity during Downsizing. The Academy of Management Journal, 42, 630-640.

Ancok, D. (2012). Kepemimpinan \& Inovasi. Jakarta: Erlangga.

Janssen, O. (2003). Inovative Behaviour \& Job Involvment at The Price Conflict and Less Satisfactory Relation With Co Workers. Journal of Occupational and Organizational Psychology, 76, 347-364.

Kasali, R.(2017). Disruption. Jakarta : Gramedia Pustaka Utama.

Kleysen, R.F., \& Street, C.T. (2001). Toward a multi-dimensional measure of individual innovative 
behavior. Journal of Intellectual Capital, 2 (3), 1469-1930.

Nitisemito, A.S. (2001). Manajemen personalia : Edisi kedua. Ghalia : Indonesia.

Robbins, S, P. (2003). Organizational behavior :Tenth Edition. Singapore: Prentice Hall.

Sari, A.N \& Ulfa, C.K (2013). Perilaku Inovasi Karyawan Ditinjau dari Empat Kuadran Iklim organisasi. Jurnal Predicara, 2 (1), 1-7.

Sarwono, Sarlito, W. (2005). Psikologi Lingkungan. Jakarta: PT. Gramedia Grasindo.
Spector, P.E. (1997). Job satisfaction : Application, assessment, Causes, and Consequences. United Satets America : Sage Publications.

Sedarmayanti. (2009). Tata kerja dan produktivitas kerja. Jakarta: Mandarmaju.

Wuri, N. \& Suhariadi, F. (2015). Hubungan antara iklim organisasi dengan perilaku kerja inovatif pada karyawan industry kreatif. Jurnal Psikologi Industri dan Organisasi, 4 (3), 356-364. 